\title{
Facilitating Group Analysis of Two Case Studies Utilising Peer Tutoring: Comparison of Tasks and Outcomes
}

\author{
Lin Siew Fong (Corresponding author) \\ Department of Social Science, Faculty of Social Science, Arts and Humanities \\ Tunku Abdul Rahman University College, Malaysia \\ E-mail: linsf@acd.tarc.edu.my
}

Received: July 31, 2016 Accepted: August 28, 2016 Published: August 29, 2016

doi:10.5296/jei.v2i2.9811 URL: http://dx.doi.org/10.5296/jei.v2i2.9811

\begin{abstract}
Peer-tutoring sessions of two groups of advanced diploma in financial accounting students with mixed proficiency were analysed thoroughly in this study. Numerous studies in peer tutoring have produced favourable results to both tutors and tutees due to the scaffolding process which promotes effective learning. However, there is a lack of studies conducted using case study as a group task in peer tutoring. Therefore, in this study, the analysis of this type of task in the course of peer tutoring is given much prominence. Video recordings of the peer-tutoring sessions were made and informants were interviewed and wrote journals in order to obtain data to be analysed. The researcher's observation notes were useful in increasing understanding of the group process. The findings revealed that there were similarities and differences pertaining to the teaching and learning experiences encountered by both tutors and tutees when analysing the two case studies. Therefore, appropriate case studies which match students' abilities are recommended to be used in peer tutoring. Furthermore, regular guidance provided by instructors for tutors is crucial in developing their confidence in playing their role.
\end{abstract}

Keywords: peer tutoring, tutors, tutees, case studies, teaching and learning, challenges, level of difficulty

\section{Introduction}

Peer education has been given much prominence in the field of education. One of the approaches in peer education is peer tutoring. Peer tutoring is a situation in which pairs or groups of peers assist one another in learning (Falchikov, 2001; Topping, 2005). A tutor is 
placed to be in charge of creating situations of learning through questioning, clarifying and scaffolding (Duran \& Monereo, 2005; Roscoe \& Chi, 2008).

Peer tutoring is not only suitable for regular learners but for students with behavioural and emotional disorders, too (Spencer, 2006). 2 distinct models of peer tutoring which are the old and new versions have been identified by Gartner and Riessman (1993). The old model is a situation in which a form of remedial work involving more capable students (tutors) helping less capable students (tutees) is carried out. The new model in comparison does not have a pre-determined tutor role, resulting in all students having the opportunity to tutor and be tutored.

Peer tutoring is promoted to be used in the classroom due to various benefits to both tutor and tutee. They are improving affective aspects in learning (Ginsburg-Block, Rohrbeck, \& Fantuzzo, 2006); increasing motivation (Wetzel, 1996); fostering communication (Höysniemi, Hämäläinen, \& Turkki, 2003); promoting positive attitude towards course (Cohen, Kulik, \& Kulik, 1982); developing key reading skills (Topping \& Lindsay, 1992); and producing economic benefits (Colvin, 2007; Miller, 2000). In addition, peer tutoring has been instrumental in even assisting students to further their studies in universities (Beasley, 1997).

\section{Theoretical Framework}

The theoretical base of this study is the social constructivist view of Vygotsky (1978). Social interaction plays an important role in the process of teaching and learning. Vygotsky (1978) states that higher psychological functions operate in the course of progressing from inter-psychological plane to intra-psychological plane. Internalisation of knowledge is made possible when knowledge obtained from peers is integrated with one's prior knowledge. Peer learning observed here is obtaining skills and knowledge through assistance from one's peers (Topping, 2005).

Peer tutoring has been used for learners from different age groups. Its use has been extended to students at different levels of studies. They range from kindergarten (Brady, 1997), elementary (Heward, Heron, \& Cooke, 1982), middle school (Nazzal, 2002), high school (Maheady, Sacca, \& Harper, 1987) to college level (Fantuzzo, Riggio, Connelly, \& Dimeff, 1989).

Class-wide peer tutoring (CWPT) is widely use and research on it has been carried out extensively. It has been found to be effective in aiding low-achieving students to improve on their spelling skills (Maheady \& Harper, 1987). Furthermore, its use has been increased in other areas and found to be successful in promoting reading and comprehension (Greenwood, 1991; Hattie, 2006; Shegar, 2006); stimulating interest in subject materials (Cheung \& Winter, 1999); providing opportunities to participate (Delquadri \& Greenwood, 1981; Maheady \& Harper, 1987) and improving language abilities (Greenwood, 1991; Otis-Wilborn, 1984).

\section{Methodology}

10 Year One students from an institution of higher learning in Malaysia pursuing their advanced diploma in financial accounting formed 2 case studies in this study. The arrangement is according to the old model proposed by Gartner and Riessman (1993) in 
which a tutor is given the role of guiding tutees in their learning. Each group was given 2 business case studies to analyse. The first business case study focused on Nike while the second one centred on millionaires who continued to work despite being rich and reaching an age they could retire.

\subsection{Informants}

Case Study 1 consisted of 5 students. There were 3 males and 2 females. They were Chu who was the tutor while Lena, Tiong, Justin and Kay were the tutees. Chu, being the tutor has the highest proficiency in English compared to the other group members.

Case Study 2, however, comprised all female students. Elsie was the tutor and the tutees were Brenda, Paula, Yan and Gab. Similar with Case Study 1, the tutor has the highest proficiency in English compared to the other group members.

All of the students were attending a Business English course required as part of their programme structure. The analysis of case studies was part of the component of enabling students to think rationally and critically. Learning outcomes to be achieved were interpreting evidence accurately, identifying relevant arguments, analysing and evaluating alternative points of view.

\subsection{Analysis of Case Studies}

The first business case study used in this study was "Some Millionaires Will Not Retire" while the second one was "NIKE Controversies". The subtasks they had to perform were reading the case studies aloud, finding out the meanings of difficult words and phrases, explaining and paraphrasing the main points in the texts and answering the questions for each case study. The informants had to answer 5 accompanying questions for each case study. The case studies were distributed to the informants a week before the session commenced so that they could make preparations. Each peer-tutoring session lasted one and a half hours. Both groups needed a total of 4 peer-tutoring sessions to attempt both case studies.

Both of the business case studies used were about 350 to 400 words long. The researcher chose these case studies because there were originally not many business terms used which could intimidate students with low proficiency. In addition, the researcher simplified the content and language in some paragraphs to make reading them easier than before.

\subsection{Data Collection}

The researcher conducted critical thinking lessons to prepare the informants for their tasks of analysing the 2 business case studies. Furthermore, the tutors were trained by the researcher for 3 hours to play their role effectively. The training module consisted of detailed discussions on firstly, the content of the case studies and secondly, acceptable answers for questions accompanying the case studies.

Upon completion of the training, the tutors proceeded to conduct their peer-tutoring sessions. The informants were divided into 2 groups to perform the analysis of 2 business case studies for a total of 6 hours with each session lasting 1.5 hours. Each group was facilitated by their 
respective tutor. The peer-tutoring sessions were audio and video-taped.

After each session of peer tutoring, both the tutors and tutees were individually interviewed. Additionally, they produced journals describing their experiences and as a means to reflect on the past session. The audio recordings and interviews were transcribed verbatim. In addition, the observation notes were also analysed thoroughly.

\section{Findings}

Data which was obtained from the spoken transcripts, diary entries, interviews and observation notes were triangulated. The findings show that there were similar and different teaching and learning experiences when performing the 2 different business case studies. The similarities were the importance of having a good command of English, teaching methods which rendered akin to responses in both case studies, prominence of concentrating on tasks and training themselves to evaluate situations from different perspectives. On the other hand, the differences in teaching and learning experiences in both case studies were apparent improvement in learning only in the second case study, tutors experiencing more difficulties in facilitating the first case study, increase of co-operation from tutees in the second case study and boost in tutors' level of confidence in the second case study.

\subsection{Similarities}

\subsubsection{Importance of Good Command in English}

It was revealed through the interviews and journals that both tutors and tutees were of the opinion that having good proficiency in English was important in analysing the case studies. Schleyer, Langdon and James (2005) found out from their study that tutors improved their communication while playing their role, too. In addition, it was observed that informants in this study who had good command of English had an advantage over their peers. It was being able to convince others of ideas when they were able to express themselves clearly. However, for tutees who faced language problems such as Justin and Kay admitted that their poor grammar caused their friends to have difficulties in understanding them and delaying them in following the discussions. Tutors with better English proficiency were able to provide scaffolding in the form of language assistance to weaker tutees. Consequently, they could perform the sub-tasks together with the deep knowledge gained.

\subsubsection{Similar Teaching Approaches}

The tutors and tutees discovered that similar teaching approaches were adopted in the facilitation of both business case studies. The session started with tutees reading the case studies aloud twice. Then the tutors explained the meanings of difficult words and summarised important points from every paragraph. Finally, discussions on answers to the questions were carried out.

It was observed that the similar teaching approaches used could be attributed to the same type of questions asked accompanying both tasks and the training which the tutors received. Firstly, the questions which tutees had to answer were Wh-questions using keywords like "what", "where", "when", "why", "which" and "how". Therefore, the same method was used 
in both case studies to elicit appropriate answers. Secondly, during the training of tutors, they were provided with sub-tasks they had to follow closely. Consequently, the overall teaching approaches they used were similar for both case studies.

\subsubsection{Concentration on Tasks}

The tutees were of the opinion that focussing on the tutors during their peer- tutoring sessions was crucial. They could form questions to ask when they realised that they failed to understand their tutors. In contrast, when they did not concentrate on the lesson taught, they might not be able to follow it successfully.

The interviews and journals revealed that some of the tutees confessed that they did not pay attention to their tutors initially and experienced difficulties in understanding the case study involved. Consequently, they interrupted the flow of the lesson when they asked questions. Therefore, being considerate and disciplined students, they decided to concentrate fully on the tutors' other peer-tutoring sessions.

\subsubsection{Evaluating Situations from Different Perspectives}

Both tutors and tutees agreed that it was important to evaluate situations in the case studies thoroughly. They believed that it would help them to obtain mature and wide perspectives of them. As a result, they could obtain quality answers to the questions accompanying the case studies.

The informants were observed to ask questions in the course of peer tutoring. The questions helped them to heighten their understanding of situations and to perceive matters from diverse groups of people. Take for example, in the first case study, they were able to relate as to why some middle-aged people refused to stop working by imagining that they were similar with their parents who had to be employed in order to support their children who were still studying at tertiary level of education.

On the other hand, the differences in teaching and learning experiences in both case studies were apparent improvement in learning only in the second case study, tutors experiencing more difficulties in facilitating the first case study, increase of co-operation from tutees in the second case study and a boost in the tutors' level of confidence in the second case study.

\subsection{Differences}

\subsubsection{Improvement in Learning Second Case Study}

Both tutors and tutees agreed that there was an obvious improvement in their learning experiences in the second case study. They opined that they were familiar with the environment during the peer-tutoring session. In addition, they were comfortable with their group members.

Both tutors and tutees were satisfied with the teaching and learning environment when analysing the second case study. The tutors were at ease with their approach in teaching while the tutees could follow their lessons easily. Elsie described through her interviews and journals that she was more "illustrative" in her explanations of points which resulted in 
enhanced learning among her tutees. Lena, Paula and Kay were satisfied with their sessions because they were productive and interesting due to their ability to prepare their answers well since they knew how the peer tutoring would be conducted.

The sessions of analysing the second case study was pleasant to both tutors and tutees because they had developed friendship with one another. The tutors, Chu and Elsie admitted that their stress level was significantly reduced compared to the earlier sessions. They attributed it to their close friendships formed in the course of peer tutoring. Furthermore, the tutees felt comfortable asking their tutors questions when they faced difficulties in following the lessons.

According to De Smet, Van Keer, and Valcke (2009), the tutor's role will change from being totally in control of their tutees to facilitating them over a period of time. At the initial stage of tutoring, the tutor may encourage participation, elicit for information and demonstrate regular learning (Pata, Sarapuu, \& Lehtinen, 2005). Gradually as the tutees gain independence in learning, the tutor's role is slowly reduced in becoming a consultant (De Smet et al., 2009). Similarly, Wilkie (2004) who studied the development of problem-based learning (PBL) tutors found themselves reducing their control after some time to allow tutees to explore problem scenarios.

\subsubsection{Tutors Facing Difficulties in Facilitating First Case Study}

The tutors admitted that the first case study was more difficult to facilitate in comparison to the second one. In addition, the tutees were observed placing much effort in learning the second case study. The difficulties experienced by the tutors and tutees were having too many answers to the questions which were subjective and the need for deep background knowledge about the predicament of retirees and the economical situations which affected their decision.

There were many choices of answer to the accompanying questions for the first case study. Therefore, tutors experienced challenges in guiding their tutees in answering the questions. It was even made complicated by having to decide if certain answers outside their own list of answers were appropriate. Furthermore, the tutees found it confusing that different answers were acceptable.

Both tutors and tutees admitted through the interviews and their journals that they did not have deep background knowledge to help them answer some questions in the first case study. The case study covered cases of millionaires who refused to retire spanning over a few decades. Therefore, the participants had to understand the situations of individuals in isolated cases in order to speculate on their decisions to continue working despite reaching retirement age.

\subsubsection{Increase of Cooperation and Participation from Tutees in Second Case Study}

The tutees commented that there was more cooperation and participation among them in the second case study compared to the first case study. There were more answers provided on the tutees' own initiative and they were well prepared for the session. As a result, the teaching and learning environment was enhanced. 
Furthermore, the tutors were satisfied with the sessions on the second case study. They described their tutees as easy to handle and enthusiastic in learning. As a result, they were able to tutor them successfully.

\subsubsection{Boost in Tutors' Level of Confidence in Second Case Study}

Both tutors and tutees observed that there was an increase in the tutors' confidence when tutoring the second case study through their interviews and journals. Brenda described her tutor, Elsie as "being in control" during the session. The former initially found her tutor "nervous and shy" when facilitating the first case study.

Similarly, Chu portrayed self-assuredness when peer tutoring the second case study. It was observed by the researcher that he seemed uncertain and confused during the first case study. In addition, he was even flabbergasted by his tutees' questions. However, during the second case study he was totally in charge and managed to make jokes during his peer tutoring.

\section{Conclusion}

The peer-tutoring sessions for both case studies show that there were similar and different teaching and learning experiences for the participants. The similarities were the importance of having a good command of English, teaching methods which resulted in same responses, importance of concentrating on tasks and training students to evaluate situations from different perspectives. On the other hand, the differences were obvious improvement in learning during the second case study, tutors experiencing more difficulties in facilitating the first case study, increase of cooperation from tutees in the second case study and boost in tutors' level of confidence in the second case study.

There are a few recommendations which can be drawn from this study. Selection of business case studies which match students' ability is crucial in peer tutoring. When the former is of the appropriate level of difficulty, both tutors and tutees will be able to teach and learn effectively. Furthermore, their stress level can be reduced.

It is suggested that tutors be provided with guidance from instructors regularly when handling case studies. This is due to the subjectivity of answers which exists and the lack of self-assurance which tutors may face. When they are provided with assistance, they will be able to play their role successfully.

\section{References}

Beasley, C. (1997). Students as teachers: The benefits of peer tutoring. In R. Pospisil \& L. Willcoxson (Eds.), Learning Through Teaching (pp. 21-30). Proceedings of the 6th Annual Teaching Learning Forum, Murdoch University, February, 1997. Perth: Murdoch University. Retrieved from http://lsn.curtin.edu.au/tlf/tlf1997/beasley.html

Brady, N. C. (1997). The teaching game: A reciprocal peer tutoring programme for preschool children. Education and Treatment of Children, 20, 123-149. http://dx.doi.org/10.1177/ 07419325070280020801

Cheung, C. C., \& Winter, S. (1999). Class-wide peer tutoring with or without reinforcement: 


\section{Macrothink}

Effects on academic responding, content coverage, achievement, intrinsic interest and reported project experiences. Educational Psychology, 19(2), 191-205. Retrieved from http://hdl.handle.net/10722/42665

Cohen, P., Kulik, J., \& Kulik, C. (1982). Educational outcomes of tutoring: a meta- analysis of findings. American Educational Research Journal, 19, 237-248.

Colvin, J. W. (2007). Peer tutoring and social dynamics in higher education. Mentor. Tutor. Partnership Learn, 15(2), 165-181.

De Smet, M., Van Keer, H., \& Valcke, M. (2009). Cross-age peer tutors in asynchronous discussion groups: a study of the evolution in tutor support. Instructional Science, 37, 87-105.

Delquadri, J., \& Greenwood, C. R. (1981). The Importance of Opportunity to Respond in the Education of the Minority Student. ERIC Document Reproduction Service No. EC 133-363. Lawrence, University of Kansas.

Duran, D., \& Monereo, C. (2005). Styles and sequences of collaborative learning in fixed and reciprocal peer tutoring. Learning and Instruction, 15, 179-199.

Falchikov, N. (2001). Learning together. Peer tutoring in higher education. London: Routledge Falmer.

Fantuzzo, J. W., Riggio, R. E., Connelly, S., \& Dimeff, L. A. (1989). Effects of reciprocal peer tutoring on academic achievement and psychological adjustment: A component analysis. Journal of Educational Psychology, 81, 173-177.

Gartner, A., \& Riessman, F. (1993). Peer tutoring: A new model. New York, NY: Peer Research Laboratory.

Ginsburg-Block, M. D., Rohrbeck, C. A., \& Fantuzzo, J. W. (2006). A meta-analytical review of social, self-concept and behavioural outcomes of peer-assisted learning. Journal of Educational Psychology, 98(4), 937-947.

Greenwood, C. R. (1991). Class-wide peer tutoring: Longitudinal effects on the reading, language, and mathematics achievement of at-risk students. Reading, Writing, and Learning Disabilities, 7, 105-123. http://dx.doi.org/10.1080/0748763910070203

Hattie, J. (2006). Cross-age tutoring and the reading together programme. Studies in Educational Evolution, 32(2), 100-124.

Heward, W. L., Heron, T. E., \& Cooke, N, L. (1982). Tutor huddle: Key element in a classwide peer tutoring system. The Elementary School Journal, 83, 114-123.

Höysniemi, J., Hämäläinen, P., \& Turkki, L. (2003). Using peer tutoring in evaluating the usability of a physically interactive computer game with children. Interacting With Computers, 15(2), 203-225.

Maheady, L., \& Harper, G. F. (1987). A class-wide peer tutoring programme to improve the spelling test performance of low-income, third- and fourth-grade students. Education and 
Treatment of Children, 10, 120-133.

Maheady, L., Sacca, M. K., \& Harper, G. F. (1987). Classwide student tutoring teams: The effects of peer-mediated instruction on the academic performance of secondary mainstreamed students. The Journal of Special Education, 21, 107-121. http://dx.doi.org/10.1177/00224669 8702100309

Miller, R. (2000). Creating Learning Communities: Models, Resources and New Ways of Thinking About Teaching and Learning. The Foundation for Educational Renewal, Brandon, VT.

Nazzal, A. (2002). Peer tutoring and at-risk students: An exploratory study. Action in Teacher Education, 24(1), 68-80.

Otis-Wilborn, A. K. (1984). The evaluation of the effects of four reading instructional procedures on the achievement of hearing-impaired children. Lawrence, University of Kansas.

Pata, K., Sarapuu, T., \& Lehtinen, E. (2005). Tutor scaffolding styles of dilemma solving in network-based role-play. Learning and Instruction, 15, 571-587.

Roscoe, R. D., \& Chi, M. (2008). Tutor learning: The role of explaining and responding to questions. Instructional Science, 36, 321-350. http://dx.doi.org/10.1007/s11251-007-9034-5

Schleyer, G., Langdon, G., \& James, S. (2005). Peer tutoring in conceptual design. European Journal of Engineering Education, 30(2), 245-254.

Shegar, C. H. (2009). Buddy Reading in a Singaporean primary School: Implications for training and research. RELC Journal, 40(2), 133-148. http://dx.doi.org/10.1177/003368 8209105864

Spencer, V. G. (2006). Peer tutoring and students with emotional or behavioural disorders: A review of the literature. Behavioural Disorders, 31(2), 204-222. Retrieved from http://search.proquest.com/docview/219676958? accountid=38945

Topping, K. J. (2005). Trends in peer learning. Educational Psychology, 25, 631-645.

Topping, K. J., \& Lindsay, G. A. (1992). Paired reading: A review of the literature. Research Papers in Education, 7(3), 199-246.

Vygotsky, L. S. (1978). Mind in Society: The development of higher psychological processes. Cambridge, MA: Harvard University Press.

Wetzel, M. (1996). Developing the role of the tutor/facilitator. Postgraduate Medical Journal, 72(850), 474-477.

Wilkie, K. (2004). Becoming facilitative: Shifts in lecturers' approaches to facilitating problem-based learning. In M. Savin-Baden \& W. Wilkie (Eds.), Challenging research in problem-based learning (pp. 81-92). Maidenhead, UK: McGraw-Hill. 


\section{Copyright Disclaimer}

Copyright for this article is retained by the author(s), with first publication rights granted to the journal.

This is an open-access article distributed under the terms and conditions of the Creative Commons Attribution license (http://creativecommons.org/licenses/by/3.0/). 